\section{Venter's Last Strand}

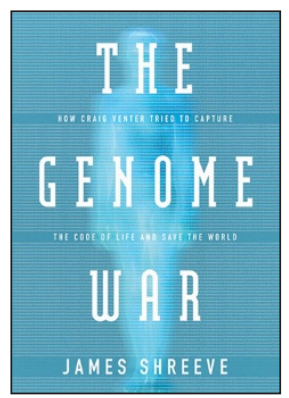

\section{The Genome War: How Craig Venter Tried to Capture the Code of Life and Save the World}

by James Shreeve

Alfred A. Knopf, 2004

403 pp. hardcover, $\$ 26.95$

ISBN 0-37540-629-8

\section{Reviewed by Robert Cook-Deegan}

The Great Genome Race of 1998-2001 is the theme of James Shreeve's long-awaited book. If you care about the story behind the first human genomic reference sequence, read this book.

Celera's side of the story is told for the first time in any detail, making this a valuable addition to earlier books on the Great Genome Race. Kevin Davies's Cracking the Code was first out of the gate. Ingrid Wickelgren's The Gene Masters and Nicholas Wade's Life Script are from journalists on the genome beat. John Sulston and Georgina Ferry's The Common Thread is a first-person account by the UK's genome guru. For a sophisticated business analysis of why genome sequencing matters, a better book is Gary Zweiger's Transducing the Genome. All are lively and well-written. Shreeve's unique contribution is his access to Celera, particularly J. Craig Venter, and his extensive insider quotes that carry the story through a turbulent voyage.

The fundamental story line is sound and the quotes are delicious, but details are shaky. Genome aficionados will cringe at errors of science and misunderstandings of law. The laboratories of the US National Institutes of Health (NIH) are not subject to the Bayh-Dole Act (but StephensonWydler); there is no 'research exemption' from patent infringement under US law (this matters, big time); erythropoietin was not used to discover a small-molecule drug but is itself a protein drug (this is right in one place, wrong in another). No more than a dozen citations anchor any chapter, and most of those are to newspaper accounts, interviews and e-mail messages. Few primary reference documents ground the story, although such documents abound. This is a popular account, not a history, and should be read and judged on that basis.

On that basis, it is a very good read. The book's value and voice come from glimpses of how decisions are made behind the corporate veil. That story is much harder to get than the one from academic and government scientists. The instinct of corporate research and development is for secrecy. We learn of Amgen's privileged 'secreted protein' access, and how past agreements were debated as though they were still in the word processor: "We agreed to send fly data to GenBank? Let's not and see if anyone notices." Skullduggery drives the story: NIH tor-

Robert Cook-Deegan is with the Institute for Genome Sciences and Policy, Duke University, Durham, North Carolina 27708, USA.

e-mail:bob.cd@duke.edu pedoes an agreement between Celera and the Department of Energy; Celera strikes at the heart of NIH's funding base at its most vulnerable point in the appropriations cycle; the Wellcome Trust leaks a letter to the press to kill negotiations between Celera and the government; Venter's boss, Tony White, secretly interviews senior staff at Celera in the run-up to sacking Venter.

We're shocked—shocked! - to learn that scientists are willing to lie for tactical advantage and to stab one another in the back. Venter is not invited to a White House Millennium Celebration on the genome, an act of deliberate pettiness, and his anguish over it is equally telling. Venter is both great and greatly flawed, absorbing body blows over and over, yet utterly unable to control his vicious tongue and thus provoking retaliation-a boxer who complains about getting hit.

Shreeve's access to Celera is not balanced on the public project side. Shreeve clearly delved into Francis Collins's personal background as well as Venter's. But that is the end of balanced treatment. In the first two parts of the book, it takes a close reading to notice that the quotes from Celera people come from private meetings, but the ones from 'public genome' figures are mainly from public meetings or press accounts (supplemented by e-mail messages and interviews). By part three, however, Shreeve has taken sides.

The cursory treatment given to the chromosome 22 sequence is a case in point. It is treated as a footnote in the story of whole-genome, shotgun sequencing (the 'right' answer). Venter surely believes that; but chromosome 22 was also a huge effort by many people that produced a concrete, useful result. It was less than one-twentieth of the genome, but it was also a milestone, and an indication that the original strategy pursued by the public genome project could work (leaving aside how quickly it could do so, which, of course, cannot be left aside). The Bermuda Principles for data release from high-throughput sequencing centers are treated in stark contrast to Sulston's The Common Thread. That is no surprise, as Celera's business plan (which, it becomes clear, was highly contingent and malleable) was incompatible with Bermuda. The Rules are mischaracterized as inherently a violation of the Bayh-Dole Act. They are not. It was when NIH policies went beyond data disclosure to discourage patents that the ice got thin. For Celera, data disclosure is a problem of business strategy. Many, however, see it as a question of how science is done. The National Research Council (NRC) directly engaged these questions in Sharing Publication-Related Data and Materials (2003). When and how to share data are deeply important for both science and commerce, and the Genome Race is a big reason why the NRC report was written.

To get the Celera story, read The Genome War; for the public genome perspective, read The Common Thread. Then compare notes. The most powerful impression that emerges from Genome Race books is how hard thousands of people worked to create a reference sequence of the human genome. Brilliant people did work of historic importance. They also generated high-stakes conflict while drowning in testosterone. Negative emotions-fear, envy, revenge, ego-driven self-promotion and greed-can make good things happen in science. This is not news. In that sense, The Genome War continues the tradition of The Double Helix, now with real money to add to the glory. 